\title{
LEMORZSOLÓDÓK TEGNAP, MA ÉS HOLNAP ${ }^{+}$
}

\author{
PUSZTAI GABRIELLA* - KOVÁCS KLÁRA - HEGEDÚS ROLAND \\ Debreceni Egyetem
}

A felsőoktatásból lemorzsolódott hallgatókról hajlamosak vagyunk sztereotípiák mentén gondolkodni, s a legutóbbi évekig a hazai szakirodalom is ritkán foglalkozott velük. A leggazdagabb statisztikai adatbázisok alapján is talányos marad a kép a felsőoktatási tanulmányok félbehagyásáról, mert a képzés félbehagyásának a tanulmányi rendszerekben megjelölhető okai nem tükrözik a realitást, s az egyes évfolyamokat követő panelvizsgálatokból épp a lemorzsolódók válaszai hiányoznak. Ennek a problémának nyomába eredve a Debreceni Egyetem Felsőoktatási Kutató és Fejlesztő Központjának (CHERD-H) kutatói elöször a lemorzsolódott hallgatók interjús (20 interjú), majd ennek tapasztalataira építve kérdőíves (605 fö) vizsgálatát végezték el, s az adataikat összevetették a teljes körü hallgatói statisztikai (FIR, FELVI), valamint a perzisztens és lemorzsolódási rizikóval küzdő hallgatók kérdőíves adatbázisaival (PERSIST 2019, $N=2000)$. Mivel az anyagi okok, a költségtérítési kötelezettség szerepe vitathatatlan a lemorzsolódásban, az önköltséges hallgatók helyzetét és összetételét is megvizsgáltuk (30 interjú, FELVI-adatok). A kutatási eredmények azt mutatják, hogy a lemorzsolódott hallgatók heterogén tábort alkotnak, s a különböző társadalmi és képzési csoportokat különböző arányban és különböző okok miatt fenyegeti a lemorzsolódás veszélye. $\mathrm{Az}$ egyéni szintű okok mellett a felsőoktatás rendszerszintü jellemzői is felelősek a lemorzsolódás növekedéséért, sőt, a kedvezőtlen társadalmi státusúak nagyobb arányú lemorzsolódásáért is.

Kulcsszavak: hallgatói lemorzsolódás, felsőoktatási perzisztencia, finanszírozási formák

We tend to identify dropout students with stereotypes, and until recent years they have rarely been addressed by the domestic literature. Even the most detailed statistical databases still leave an incomplete picture of them, and they even miss from the panel studies. Researchers at the Center for Higher Education Research and Development University of Debrecen conducted 20 interviews and questionnaire survey $(N=605)$

A 123847 számú projekt a Nemzeti Kutatási Fejlesztési és Innovációs Alapból biztosított támogatással, a K_17 pályázati program finanszírozásában valósult meg. A tanulmány megírását a Bolyai János Kutatói Ösztöndíj támogatta.

* Levelező szerző: Pusztai Gabriella, 4032 Debrecen, Egyetem tér 1.

E-mail: pusztai.gabriella@arts.unideb.hu 
with dropout students, and compared their data to databases of persistent and at-risk students (PERSIST 2019, $N=2000$ ). Since the financial reasons play an important role in dropout, we also examined the social and regional composition of fee paying students (based on 30 interviews and statistical data of admitted students). Results show that the dropouts heterogeneous group composed of four distinct subgroups, with different social and educational background, who are in danger due to different reasons. In addition to individual-level causes, system-level characteristics of higher education are also responsible for the increase in dropouts. The disadvantaged students are at-risk in a higher proportion.

Keywords: student dropout, higher education persistence, funding

\section{A lemorzsolódás problémája}

1 lemorzsolódás okát a közvélemény, és sokszor a szakértők is, a tanulók felelőtlenségével, hanyagságával, halogatásra való hajlamával, gyengébb képességeivel szeretik magyarázni. Azonban ha egyes társadalmi és képzési szegmensekben majd minden második hallgatót a túlfutás vagy a tanulmányok félbehagyása fenyegeti, érdemes a társadalmi és rendszerszintű gyakoriságot és összefüggéseket adatnak tekinteni, s a jelenséget társadalmi tényként vizsgálni (Fehérvári 2015; Fenyves et al. 2017; Dinyáné-Pusztai-Szemerszki 2019). Mindjárt leszögezzük, hogy a tanulmányokkal kapcsolatos önbizalmat, motivációt, hatékonyságérzést, sőt, a szövegértési és a szövegalkotási kompetenciát is döntően társadalmi státusban gyökerező kulturális különbségek következményének tekintjük (Bourdieu 1978; Tierney 2000).

A jelentős arányú lemorzsolódás egyidős a felsőoktatás tömegessé válásával (Tinto 1975). A felsőoktatás bolognai reformja abban a reményben történt, hogy a rövid ciklusú alapképzésekben többen és gyorsabban szereznek majd diplomát (Pusztai-Szabó 2008). A struktúraváltás azonban nem mérsékelte a lemorzsolódást, s a 2010-es években is az egyik legjelentősebb felsőoktatás-kutatási kihívás maradt a jelenség megértése, különösen régiónkban (Tinto 1975; Braxton 2000; Brunsden et al. 2000; Schnepf 2014; WolterDiem-Messer 2014; Merill 2015). A környező országokban is nagyarányú a diplomát nem szerző hallgatók aránya (Stiburek-Wlk-Svec 2017; Hatos-Pop 2013). Magyarországon is indokolt a lemorzsolódás törvényszerüségeinek vizsgálata, hiszen a statisztikai adatok szerint a beiratkozók kétötöde az alapképzést, egyötöde a mesterképzést, fele a doktori képzést hagyja el végzettség nélkül (Derényi 2015; Kozma-Pusztai 2009).

A probléma első jelentős kutatói is elkülönítették egymástól a lemorzsolódás különböző okait: a felsőoktatás széteső struktúrája miatt nem tudja integrálni a hallgatót vagy a hallgató nem képes elsajátítani a felsőoktatás normáit, vagy esetleg a túlszabályozott környezet teszi lehetetlenné a hallgatói továbbhaladást (Tinto 1993). A sikertelen hallgatói szocializációért sokan a felsőoktatás szelektív kultúráját, az intézmények és az oktatók elit habitusát okolják (Tierney 2000; Pascarella-Terenzini 2005; Reay-Crozier-Clayton 2009). Az egyéni okok mellett a felsőoktatási rendszerek jellegzetességeitől és a felsőoktatás-politikától sem független a lemorzsolódók aránya, így elengedhetetlen feladat a nemzeti rendszerek szintjén végzett vizsgálat (Kebm 2014; Kehm-Larsen-Sommersel 
2019; Thomas 2019). A felsőoktatási rendszerek nemzetközi összehasonlításban a bejutás és a diplomaszerzés társadalmi egyenlőtlenségei alapján is jellemezhetők. A lemorzsolódás, a relatíve alacsonyabb diplomaszerzési arányok kedvezőtlen képet nyújthatnak egy felsőoktatási rendszerről vagy intézményről, a jelentkezők körében rossz színben feltüntetve ezeket.

A jelen tanulmányban bemutatott kutatási eredmények arra vallanak, hogy a lemorzsolódás társadalmi és regionális szempontból egyenlőtlenül sújtja a hallgatókat. A nemzetközi kutatások szerint a tömeges felsőoktatásba bekerülők között kétszer annyian vannak a magas társadalmi státusú családokból származók, mint az alacsony státusúakból, de az alacsony státusúak közül tizedannyi végez (Vossensteyn et al. 2015). Tény, hogy a lemorzsolódás miatt a felsőoktatás nem tölti be a legmagasabb iskolai végzettséghez való hozzáférés egyenlötlenségének mérséklése tekintetében várható szerepét.

A longitudinális elemzések arra a következtetésre jutottak, hogy a lemorzsolódási ráta növekedését makroszintű okok, elsősorban a felsőoktatás-politika, mezoszintű okok, mint a felsőoktatási kurrikulum struktúrája, az elméleti és a gyakorlati kurzusok aránya és a növekvő tanulmányi költségek magyarázzák (Arulampalam-Naylor-Smith 2007; O’Neill et al. 2011; Kehm 2014). A lemorzsolódás befolyásos okaként jelennek meg a tanulmányokkal összefüggő költségek okozta nehézségek, a tanulmányok melletti munkavállalás negatív hatásai, a hitelből finanszírozott tandíjak okozta eladósodástól való félelem (Ross et al. 2006; Hübner 2009; Dwenger-Storck-Wroblich 2012; Pusztai-Kocsis 2019). A mikroszintű okok az egyén társadalmi-gazdasági hátteréből, közoktatási pályafutásából, tanulmányi felkészültségéből és eredményeiből származnak.

Létezik olyan interpretáció, amely a lemorzsolódást nem tekinti patológiás jelenségnek. A felsőoktatás egy szelektív modelljében az alkalmatlanok kirostálása, egy alacsonyabb képzési szint felé való visszafordítása kívánatosnak tűnik, $\mathrm{s}$ a diploma nélkül sikeresen elhelyezkedők keresete nem mindig arányosan alacsonyabb (Kun 2015; Schnepf 2014). Olyan értelmezés is lehetséges, hogy nem feltétlenül a diplomaszerzés tekinthető eredménynek. A lemorzsolódók egy másik képzésben végül diplomát szerezhetnek, s minden egyes felsőoktatásban eltöltött év hozzájárul a humán tőke felhalmozáshoz, s minden bent töltött évvel nő az oktatásba való visszatérés és a későbbi sikeres diplomaszerzés esélye. Mások a szellemi és pszichés vonatkozásban is érlelő felsőoktatási évek hasznát hangsúlyozzák, még ha diplomaszerzés nélkül is érnek ezek véget (Merill 2015). Az oktatáspolitikai szakértők visszatérö gondolata, hogy a hallgatók számának csökkentése és a hallgatónak a képzés finanszírozásába való bevonása oldja meg a lemorzsolódás gondjait. A magyarázat szerint a költségtérítéses képzésben tanulók arányának növelése felelősebb hallgatói magatartást eredményez. A megállapítás mögött az a hipotézis állhat, hogy a lemorzsolódás és a túlfutás egyszerüen a hallgatói felelőtlenségnek tudható be, s ebben a megvilágításban a költségek megtéríttetése akár egyfajta nevelési eszköznek is tűnhet.

Kutatásunk során a lemorzsolódást a tanulmányi karrier negatív eseményének tekintettük, ami miatt a hallgatónak (és családjának) a felsőoktatási tanulmányokkal kapcsolatos várakozásai meghiúsulnak. Össztársadalmi, egyéni és intézményi szinten is felmerül az emberi és az anyagi erőforrások elvesztegetése (Pervin-Reik-Dalrymple 1996). Rendszerszinten ilyen veszteségek a hallgató képzésére fordított korábbi befektetés, a felsőoktatási karrier korrekcióját szolgáló állami kiadások, a potenciális diplomásban talán örökké rejtve maradó tehetség, innovációs potenciál és a diplomás adófizetőkből nyerhető többlet is elvész, ehelyett viszont számításba jönnek a kudarcos karrier okozta szo- 
ciális és egészségügyi problémák kezelésére irányuló kiadások. Az egyén (és a családok) szintjén az elmaradó társadalmi és kulturális mobilitás okozta elégedetlenség növekedését okozza az elérhető alacsonyabb bérezés, az alacsonyabb végzettség miatt nagyobb munkanélküliségi rizikó, a kudarcos felsőoktatási karrier nyomán megjelenő pszichés és egészségügyi problémák. Ha ez szisztematikusan sújtja az alacsonyabb státusú, a felfelé kapaszkodó, de szinte folyamatosan lecsúszás által fenyegetett, alsó-közép rétegekhez tartozó családokból származókat vagy aszimmetrikusan jellemez egy-egy intézményt, sőt régiót, annak súlyos, hosszú távú társadalmi hatásai lehetnek (Seidman 2005; FényesPusztai 2006; Pusztai 2011; Szemerszki 2015).

Tanulmányunkban a lemorzsolódás egyéni és rendszerszintű okait vizsgáljuk meg. Először a már lemorzsolódott hallgatókkal foglalkozunk. A lemorzsolódottakat először interjús vizsgálat keretében kerestük meg, s a tanulmányi életútjukról kérdeztük őket. A hallgatói narratívák elemzése során plasztikus kép bontakozott ki azzal kapcsolatban, hogy melyek a lemorzsolódáshoz vezető út kritikus pontjai. A kvalitatív elemzés tapasztalatai alapján összeállított kérdőívvel 605 lemorzsolódott hallgatót kerestünk meg, s adataikat részletes elemzésnek vetettük alá. A lemorzsolódás hallgatói magyarázatai alapján klaszteranalízist végeztünk. A hallgatók négy nagy csoportba rendeződtek, s nemcsak a tipikus szcenáriók, hanem számos háttérváltozó alapján jól elkülöníthető típusokat alkottak. Mivel a financiális okok a lemorzsolódás többféle szcenáriójában is lényeges szerepet játszottak, a kutatás során külön figyelmet szenteltünk azoknak, akiknek anyagi terhei az átlagosnál magasabbak. Ez a lemorzsolódási rizikónak kitett csoport a költségtérítéses hallgatóké, akik körében nemcsak interjús vizsgálatot végeztünk, hanem a felsőoktatási statisztikákból kirajzolódó jellemzőiket is kerestük. A kutatási eredmények azt mutatják, hogy a költségtérítés nemcsak lemorzsolódást segítő tényező, hanem már a jelentkezéskor társadalmi és regionális egyenlőtlenségek mentén jelenik meg a felsőoktatási rendszerben.

\section{Kik a lemorzsolódott hallgatók?}

Az interjús kutatással megalapozott kérdőíves adatfelvétel (DEPART 2018, $N=605$ ) során olyan volt hallgatókat kerestünk fel, akik az elmúlt 10 évben diplomaszerzés nélkül félbehagyták felsőoktatási tanulmányaikat valamely magyarországi (és néhány határon túli) felsőoktatási intézményben, 605 volt hallgató válaszait elemeztük. A lemorzsolódás okai mentén négy lemorzsolódott hallgatói típust különböztettünk meg és hasonlítottunk össze a vizsgált dimenziókban: 1) az anyagi és munkavállalási okok miatt lemorzsolódók, 2) a tanulmányi nehézség és intézményi támogatás híján lemorzsolódók, 3) a szakban és továbbtanulásban csalódók, 4) az egyszerre többféle problémával is küzdők (Pusztai et al. 2019). Az első típusba tartozó lemorzsolódottak családja nem tudta finanszírozni a tanulmányok költségét. Noha a megkérdezettek még a költségtérítéses képzésre való átsorolás bevezetése előtti periódusban léptek be a felsőoktatásba, a tanulmányok költségeit (taneszköz, informatikai eszköz, útiköltség, megélhetés, lakhatás stb.) mégsem tudták fedezni (Pusztai et al. 2019). A második típusba tartozó hallgatóknak a felsőoktatási intézményben folyó tevékenységek során szaporodtak fel a nehézségei, melyeknek egy része tanulmányi természetű, másik része viszont a felsőoktatás bonyolult szervezeti rendszerében való eligazodási, elsősorban információs és adminisztrációs problémákkal magyarázható, melyet ők az akadályozó intézményi környezettel magya- 
ráztak. A továbbtanulásból, illetve a választott szakból kiábrándulók a továbbtanulást előkészítő döntés során szenvedtek hiányt a választáshoz szükséges támogatásban, ami a tanulók mellett a szülők, a pedagógusok és a pályaválasztási rendszer felkészületlenségéből, alulinformáltságából fakadt. Az egyszerre többféle problémával is küzdők száma indokolttá tette, hogy külön csoportként kezeljük őket, de leginkább az első két típus hátrányai összefonódva okozták kudarcukat. A lemorzsolódott hallgatói típusokat az iskolai pályafutás, a tanulmányi tapasztalatok, a család tanuláshoz való viszonya, a pályaorientáció, a felsőoktatási tanulmányi és társas tapasztalatok, a versengő tevékenységek és a szocioökonómiai jellemzők alapján hasonlítottuk össze (Markos-Kocsis-Dusa 2019; Váradi-Demeter-Karászi-Kovács 2019). A lemorzsolódottak képzési terület szerinti összetétele jellegzetes, a leginkább érintettek a műszaki, informatikai, gazdaság- és jogtudományi, orvos-egészségtudományi területen tanulók. Az anyagi okok miatt lemorzsolódók a műszaki, orvos-egészségtudományi, informatikai és jogi területen, a tanulási nehézségeket és az intézményi támogatás hiányát elszenvedők a gazdasági, műszaki, informatikai és természettudományi képzésekben, a több problémával küzdők a bölcsész, gazdasági, műszaki és természettudományi, a kiábrándulók a gazdasági, műszaki, informatikai és természettudományi képzésben voltak a gyakoribbak.

Az anyagiak a lemorzsolódás egyik perdöntő oka. Az anyagi okok és munkavállalás miatt lemorzsolódók jellemzően alacsony társadalmi státuszú családokból érkeznek: körükben a legmagasabb az alacsony iskolai végzettségü szülők aránya, legkevésbé jellemző rájuk a kultúrafogyasztás, s ők vannak a legrosszabb anyagi helyzetben. A többféle problémával küzdő lemorzsolódók szociális háttere szintén igen heterogén: az átlagnál többen vannak, akiknek a családja anyagi gondokkal küzd, idősebbek az átlagnál és felülreprezentáltak köztük a nők. Szüleik iskolai végzettsége is vegyes, jellemzően középfokú vagy alacsonyabb. Ezzel szemben a szakban és továbbtanulásban csalódók társadalmi háttere a legjobb: a legmagasabb arányban találhatjuk körükben diplomás szülők gyerekeit, anyagi helyzetüket nagyon jónak ítélik meg, így látható, hogy ezek a lemorzsolódott hallgatók családi mintát, esetleg elvárást követnek a felsőoktatási tanulmányokkal, amelyek nem minden esetben állnak összhangban saját elképzeléseikkel, céljaikkal.

A lemorzsolódottak nem a gyengébb jelentkezők. A lemorzsolódott hallgatók kilenctizede intrinzik motivációval, tudásszomjjal telve jelentkezett felsőoktatásba. Körükben is erős befolyásoló tényezőnek bizonyult a diplomával való könnyebb elhelyezkedés reménye $(76,2 \%)$ és a jól jövedelmező $(68,8 \%)$, elismert $(68,2 \%)$ foglalkozás utáni vágy is. A kutatás lényeges eredménye, hogy a középiskolai pályafutásuk alapján a lemorzsolódottak nem a gyenge tanulók közül kerülnek ki. A válaszadók majd egyharmada (30\%) kiemelkedő teljesítményt nyújtott a felvételin, hiszen emelt szintü érettségi vizsga letétele miatt többletpontra is jogosult volt. A lemorzsolódott válaszadók 28\%-a igényelt többletpontot középfokú nyelvvizsga meglétéért, amit a már két emelt szintű érettségivel rendelkezők nem tettek meg. Elgondolkodtatónak találtuk, hogy éppen az emelt szintű érettségivel és felsőfokú nyelvvizsgával rendelkezők, a tanulmányi versenyekért többletpontot igénylők között volt kiemelkedő azoknak az aránya, akik tanulmányi problémák vagy intézményi támogatás hiányában morzsolódtak le. Ez arra vall, hogy az ő képességeikkel nem tudott jól gazdálkodni a felsőoktatás.

A felsőoktatási intézmények szervezeti problémáiról árulkodik, hogy a tanulmányi és intézményi okok miatt lemorzsolódók az oktatói inkorrektséget, az információkat 
visszatartó adminisztratív szakembereket okolták kudarcaikért. A hallgatók és az oktatók kapcsolatrendszerének vizsgálata alapján egyértelmü, hogy a hazai felsőoktatásban a hallgatók kevesebb mint egyötöde részesül olyan oktatói figyelemben, ami a fejlődéséhez szükséges lenne (Pusztai 2011).

A lemorzsolódottak 30\%-a számolt be olvasás és szövegértés terén megjelenő problémáról felsőoktatási tanulmányai kapcsán. Többségük nehezen tudta a tankönyveket, jegyzeteket feldolgozni, s néha problémát jelentett neki, hogy megértse, amit olvas. Mindez különösen annak fényében számít nagyon magas aránynak, hogy közülük alig valamivel többen $(2,9 \%)$ kaptak többletpontot részképességzavart megállapító szakértői véleményre, mint az ilyen problémáról nem beszámoló hallgatók (1,9\%), ami a fel nem ismert és a közoktatási évek alatt végig rejtőzködő olvasási nehézségről árulkodik. Fontos azonban hangsúlyozni, hogy ezek a hallgatók lehetnek nagyon jó képességüek, tehetségesek, sőt, akár tehetségesebbek is az átlagnál, hiszen óriási akaraterővel és szorgalommal kompenzálva olvasási nehézségeiket feltáratlan és kezeletlen tanulást nehezítő problémát hurcoltak magukkal a felsőoktatásba anélkül, hogy ezt felismerte vagy kezelte volna valaki. A tanulmányi nehézségekre panaszkodók viszont többen szereztek középfokú komplex nyelvvizsgát (37,9\%), mint társaik Az olvasási és szövegértési problémákkal küzdő lemorzsolódottak között felül vannak reprezentálva a férfi hallgatók, és maga a lemorzsolódás is a férfiakat veszélyezteti jobban.

A családi támogatás hiján diákmunkát vállalók az egyik kockázati csoport. Megdöbbentő eredmény, hogy a lemorzsolódott hallgatókat kiemelkedő arányban érintik a családi problémák. 40\%-uknál nem volt a háttérben egy stabil család, mert már a felsőoktatásba lépéskor vagy később elváltak a szülei. Ez természetesen nemcsak lelki terhet, hanem anyagi gondokat is maga után vont. A felsőoktatásból lemorzsolódott válaszadók négyötöde úgy érezte, hogy szülei fontosnak tartják a tanulást, de majd minden második családban nem az iskolában megszerezhető tudást tartják fontosnak. A felsőoktatási tanulmány finanszírozása a családoknak komoly anyagi terhet jelent. Lényeges probléma az is, hogy a családok egyetemista gyermekeik után már nem jogosultak családtámogatásokra. A lemorzsolódott hallgatók nem kaptak tanulmányi és szociális ösztöndijat, ha kaptak, ennek összege jelképes volt. Ha a hallgatóknak még költségtérítést is kellett fizetniük, ez túlzott munkavállaláshoz vezetett, mely munkának a területe a legritkábban kapcsolódott a tanulmányi területükhöz (Pusztai-Kocsis 2019).

A lemorzsolódott hallgatók majd kétharmada dolgozott az egyetemi tanulmányai alatt. Majd egyharmaduk önkéntes munkát végzett, de ugyanennyien fizetett munkát. A rászorultság mellett a munkatapasztalat szerzése céljából vállalták ezt a pluszfeladatot, ami sok esetben elvonta őket a tanulmányaiktól, s nem is kapcsolódott a szakterületükhöz. Az is kiderült, hogy a lemorzsolódott hallgatók nagyon kevéssé jutnak hozzá minőségi szabadidős programokhoz, egyesületi tagsághoz (művészet, sport stb). Az intézményi programkínálatban is a tömegrendezvények, a bulizás kapott szerepet, nem a közösségépítés. Lényeges eredmény, hogy a lemorzsolódók azon csoportja, akik tanulmányi problémákra hivatkoztak és az intézményi támogatás hiányát okolták a kudarcukért, a legritkábban jártak szórakozni.

$\mathrm{A} z$ adatok azt mutatják, hogy a szülőkre, a családon belüli társadalmi tőkére (Pusztai-Szigeti 2018) nagy szükségük van a hallgatóknak a felsőoktatási években. Az anyagi támogatás mellett a bátorítás, a vizsgákról és a tanulmányokról való érdeklődés is fontos hozzájárulás, amit a perzisztensek megkapnak, s a kockázatban lévők kevésbé, a lemor- 
zsolódottak közül azonban ezt a támogatást csak a kisebbség kapja meg. A felsőoktatást diploma nélkül elhagyó hallgatók majd kétharmada nem beszélte meg családjában, hogy gondjai adódtak a tanulmányai folytatásával, így magányosan sodródtak a lemorzsolódás felé. Az adatokból az is kiderült, hogy a lemorzsolódás küszöbére kerülö, veszélyeztetett hallgatók a felsőoktatási intézményektől sem kapnak segítséget.

A téves pályaválasztási döntésnek komoly ára van. Jelentős tábort képeznek azok a hallgatók, akik a nem megalapozott pályaválasztás, a képzésből való kiábrándulás eredményeképpen hagyják abba tanulmányaikat. A felsőoktatási intézmény falain túlra, a közoktatást lezáró ciklusra mutat vissza ez a problémakör, a középiskola pályaorientációs funkciójának működésképtelenségére. Ilyen esetben a lemorzsolódás egy hibás tovább-

1. táblázat: A lemorzsolódottak csoportjainak legfontosabb jellemzői

\begin{tabular}{|c|c|c|c|c|}
\hline & $\begin{array}{l}\text { Anyagi és munka- } \\
\text { vállalási okok mi- } \\
\text { att lemorzsolódók }\end{array}$ & $\begin{array}{l}\text { Tanulmányi, in- } \\
\text { tézményi okokból } \\
\text { kimaradók }\end{array}$ & $\begin{array}{l}\text { Többféle okot } \\
\text { megjelölő lemor- } \\
\text { zsolódók }\end{array}$ & $\begin{array}{l}\text { Szakban és } \\
\text { továbbtanulásban } \\
\text { csalódók }\end{array}$ \\
\hline Kor & 29,6 év & 27,8 év & $\begin{array}{l}\text { 30,9 év (többen } \\
\text { családosok) }\end{array}$ & 27,7 év \\
\hline Nem (nő) & $50 \%$ & $60 \%$ & $60 \%$ & $50 \%$ \\
\hline $\begin{array}{l}\text { Felsőfokú vég- } \\
\text { zettségű anyák }\end{array}$ & $33,3 \%$ & $35,4 \%$ & $26,5 \%$ & $41,6 \%$ \\
\hline $\begin{array}{l}\text { Szubjektív anyagi } \\
\text { helyzet }\end{array}$ & $\begin{array}{l}\text { rendszeresek a } \\
\text { családban a min- } \\
\text { dennapi anyagi } \\
\text { gondok }(30,2 \%)\end{array}$ & $\begin{array}{l}\text { mindene megvolt, } \\
\text { de jelentősebb } \\
\text { kiadásokra nem } \\
\text { telt }(63,7 \%)\end{array}$ & $\begin{array}{l}\text { rendszeresek az } \\
\text { anyagi gondjaik } \\
(24,5 \%)\end{array}$ & $\begin{array}{l}\text { jelentősebb } \\
\text { kiadásokra is telt } \\
(22,8 \%)\end{array}$ \\
\hline $\begin{array}{l}\text { Törések a család- } \\
\text { szerkezetben }\end{array}$ & $47,2 \%$ & $34,5 \%$ & $35,3 \%$ & $25,6 \%$ \\
\hline $\begin{array}{l}\text { A család tanulás- } \\
\text { hoz kapcsolódó } \\
\text { viszonya }\end{array}$ & $\begin{array}{l}\text { mindig fontosnak } \\
\text { tartották a tanu- } \\
\text { lást }(80,7 \%)\end{array}$ & $\begin{array}{l}\text { elvárásaiknak } \\
\text { soha nem tudott } \\
\text { eléggé megfelelni } \\
(32,4 \%)\end{array}$ & $\begin{array}{l}\text { hagyták, hogy } \\
\text { eldöntse, mit } \\
\text { szeretne tanulni } \\
(85,4 \%)\end{array}$ & $\begin{array}{l}\text { elvárásaiknak } \\
\text { soha nem tudott } \\
\text { eléggé megfelelni } \\
(24 \%)\end{array}$ \\
\hline $\begin{array}{l}\text { Továbbtanulási } \\
\text { motivációk }\end{array}$ & $\begin{array}{l}\text { társadalmi mo- } \\
\text { bilitás reménye } \\
(69,6 \%) ; \text { nem } \\
\text { kellett tandíjat } \\
\text { fizetnie }(66,2 \%)\end{array}$ & $\begin{array}{l}\text { jól jövedelmező } \\
\text { állást találjon } \\
\text { (72\%); diplomával } \\
\text { könnyebb elhe- } \\
\text { lyezkedni }(78,8 \%)\end{array}$ & $\begin{array}{l}\text { gyarapítsa a } \\
\text { tudását }(92,9 \%)\end{array}$ & $\begin{array}{l}\text { megengedhet- } \\
\text { te magának } \\
\text { anyagilag ( } 43 \%) ; \\
\text { még nem akart } \\
\text { dolgozni }(32 \%)\end{array}$ \\
\hline $\begin{array}{l}\text { Olvasási és } \\
\text { szövegértési } \\
\text { problémái voltak } \\
\text { a felsőoktatásban }\end{array}$ & $35,2 \%$ & $45,8 \%$ & $11,1 \%$ & $33,3 \%$ \\
\hline $\begin{array}{l}\text { Fizetett munka } \\
\text { a tanulmányok } \\
\text { mellett (legalább } \\
\text { havonta) }\end{array}$ & $\begin{array}{l}\text { gyakran, rend- } \\
\text { szeresen } 60,2 \%\end{array}$ & soha $49 \%$ & $\begin{array}{l}\text { rendszeresen } \\
34,9 \%\end{array}$ & $39,8 \%$ \\
\hline
\end{tabular}

Forrás: DEPART 2018. Megjegyzés: A táblázatban azokat a jellemzőket emeltük ki, ahol egy kategóriában felülreprezentáltan voltak jelen az egyes típusok. 
tanulási döntés korrekciójáról szól, esetleg a megcélzott szak helyett egy vigaszágon kiválasztott képzés elkezdéséről. A hibás pályaválasztási döntés nemcsak a tanuló adottságainak téves felismeréséből, hanem a tanácsadásban részt vevőknek a felsőoktatási rendszerről és a munkaerőpiaci lehetőségekről alkotott téves elképzeléseiből táplálkozik. Ennek a hibás pályaválasztási döntésnek a költségeit (elvesztegetett idő, elveszített állami támogatású félévek stb.) a hallgató és a családja fizeti meg. A képzésben való csalódás másik oka a korszerűtlen felsőoktatási tananyag és munkaformák miatti kiábrándulás, hiszen a hallgatóban felmerül, hogy amit tanul, az hasznos-e, érvényes-e, s ahogyan oktatják, az effektív-e. Kivétel nélkül minden elemzésünkben a lemorzsolódást megelőlegező fenyegető jelnek bizonyult a passzív félévek igénybevétele. A felsőoktatási kurrikulum szerkezete, az indokolatlanul sok előfeltételt tartalmazó mintantervek azt a rejtett üzenetet hordozzák magukban, mintha nem a hallgató fejlesztése, formálása, hanem szankcionálása lenne a felsőoktatási képzés célja. Az intézményekben ritkán találnak megoldást arra, hogy a hallgatót bevonják, érdekeltté tegyék a saját fejlődésében, $\mathrm{s}$ ezt ne extrinzik, kredencialista motivációk mozgósításával próbálják megtenni. A szakváltás vagy szakváltogatás gyakran a kudarcos felsőoktatási pályafutásnak a végleges lemorzsolódás előtti fázisa. A hallgatók nagy része szakot is azért vált, mert csalódott a képzésben. Ez ellen a pályaorientáció rendszerének kidolgozásával lehetne tenni, de addig is a korai korrekciót szükséges támogatni rugalmasabb oktatásszervezéssel, kreditelismeréssel, az első év után a támogatott félévek újrakezdésének lehetőségével. A bulizás és az ezekhez szorosan kapcsolódó nagyivászat és a sportolás a szakban és továbbtanulásban csalódókra volt a legjellemzőbb egyetemi éveik alatt.

\section{Kik a jövendő lemorzsolódói?}

A 2019-ben végzett hallgatói kérdőíves vizsgálatunkban a lemorzsolódási rizikó kiszürésére a korábbi vizsgálataink során is használt perzisztencia kérdéssort alkalmaztuk. A diplomaszerzésben bizonytalan, lemorzsolódási rizikóval jellemezhető hallgatók és a perzisztensek elkülönítése után logisztikus regressziós modellekkel vizsgáltuk, hogy milyen tényezők növelik leginkább a lemorzsolódási rizikóval jellemezhetők csoportjába kerülés esélyét. A z elemzés során a munkavállalás, a passzív félévek, illetve azok halmozódása, s ezzel szoros összefüggésben az anyagi helyzet és annak megítélése konzekvensen befolyásos tényezőnek bizonyult a rizikócsoportba kerülés szempontjából. Az oktatási statisztikák azt mutatják, hogy az önköltséges képzést vállalók aránya tartósan 40\% fölött van, azonban ez a csoport nem részesülhet tanulmányi vagy szociális ösztöndíjban, ez csak az államilag támogatott képzésbe járókat illeti meg, s közülük is csak kevesen jutnak hozzá.

A magyarországi hallgatók anyagi terheiről sokat tudnak a családok, de keveset az oktatáskutatók. A felsőfokú tanulmányok jelentős anyagi terhet jelentenek a családoknak, hiszen egy vagy több felnőtt gyermek megélhetési, lakhatási, közlekedési, kulturális kiadásait és a felsőfokú tanulmányok tankönyv- és taneszköz szükségleteit kell biztosítaniuk. Ezeket a hallgatói juttatások rendszere van hivatva kompenzálni, azonban Magyarország sajátos modellt képvisel, hiszen hallgatói juttatásokat csak azok kaphatnak, akik államilag támogatott képzésben tanulnak. Nálunk a legalacsonyabb Európában (az Eurydice adatai szerint évi 1000 euró alatti) az elérhető hallgatói juttatások összege, s hazánk egyike azoknak az országoknak, ahol arányaiban a legkevesebb hallgató juthat ehhez hozzá, hiszen legfeljebb minden negyedik hallgató kap valamilyen juttatást. A má- 
sik pólust a négy skandináv ország képezi, ahol minden hallgató megélhetési és kulturális költségeihez hozzájárul az állam. A magyar hallgatóval szemben az államilag támogatott diákhiteleket is a jómódú skandináv országok és Anglia fiataljai veszik igénybe legnagyobb arányban (Eurydice 2018).

Magyarország azon kevés európai országok egyike, ahol a felsőoktatási hallgató szülei nem részesülnek sem adókedvezményben, sem családtámogatásban, miközben 22 európai felsőoktatási rendszerben elismerik a szülők gyermekeik tanulmányaiért hozott áldozatait.

A felsőoktatási expanzió társadalmi gyökerủ dinamikáját az oktatási kormányzatok aktivitása is befolyásolja. A belépők számának, képzésterületi arányának szabályozása mellett a finanszírozási terhek elosztásával képes ezt megtenni (Diem-Wolter 2019). A visszavonuló állam az 1980-as évektől igyekszik megosztani a felsőoktatási képzés költségeit a hallgatókkal és a családokkal. Egy európai adatgyüjtés a 2017/18. tanévben vizsgálta meg, hogy hogyan alakulnak a hallgatók költségei a különböző országokban (Eurydice 2018). Költségeken nemcsak tandíjat, hanem regisztrációs díjat, vizsgadíjakat, adminisztratív költségeket, hallgatói szervezetek tagdíját is figyelembe vették. Mindössze négy nyugat-európai ország van, ahol minden egyes hallgató díja meghaladta a szemeszterenkénti 50 eurót. Angliában kell a legtöbbet fizetni az első diploma megszerzéséért a hazai hallgatóknak, ez az összeg meghaladhatja a szemeszterenkénti 1500 eurót. Európában Magyarország mellett hat olyan ország van, ahol akár szemeszterenként 500 eurót meghaladó összeg terhelheti a nappali képzésben részt vevőket.

A tanulmányi eredményekhez kötött állami finanszírozás azt jelenti, hogy a hallgatónak meghatározott tanulmányi eredményt kell felmutatnia ahhoz, hogy állami támogatott képzésben tanuljon. Magyarország mellett a kelet-európai és a balkáni posztszocialista (Lettország, Litvánia, Románia, Bosznia és Hercegovina, Szerbia és Macedónia) országokra jellemző, hogy a középiskolai és a felvételi eredmények alapján sorolják a hallgatókat állami vagy költségtérítéses képzésbe, de később is elveszíthetik államilag finanszírozott helyüket. A meghatározott szemeszterenkénti kreditszámhoz kötött teljesítményalapú finanszírozás az összes posztszocialista országban, valamint a német nyelvü és a dél-európai országokban müködik, s a szemeszterenkénti 25-30 kredit számít megfelelő teljesítménynek. A túlfutásért egy rövidebb türelmi idő után szintén több országban fizetni kell (Eurydice 2018).

2012-től Magyarországon bevezették a teljesített kreditekhez kötött finanszírozás rendszerét, majd 2015-től a tanulmányi átlagokhoz kötött finanszírozás rendszerét. $\mathrm{A} z$ új szisztéma évente felülvizsgálja a hallgatók tanulmányi előrehaladását (minimum 36 kredit) és a kreditértékek szerint súlyozott érdemjegyeinek átlagát (minimum 3,253,0), s akinek a tanulmányi átlaga vagy a kreditszáma ennél alacsonyabb, az elveszíti az államilag támogatott státuszát, s akár évente több mint 8000 euro költségtérítést is fizethet, ha folytatni szeretné a tanulmányait. Ez egy szülö egy havi minimálbérének a 8,5-szerese. Ennek alapján egyértelmü, hogy a költségtérítéses hallgatók arányának növekedése prognosztizálható.

\section{Lemorzsolódási rizikó és költségtérítéses képzés}

2019 tavaszán költségtérítéses hallgatókkal készítettünk interjúkat $(N=30)$. A költségtérítéses hallgatók egy része a jelentkezéskor dönt a költségek vállalása mellett, egy másik 
részük a felvételi besorolás után vállalja fel, s a harmadik csoportjuk a tanulmányok alatti átsorolás után dönt arról, hogy az állami finanszírozás megvonása után önköltségesként is megpróbálja folytatni tanulmányait. A megkérdezetteket három típusba soroltuk, költségtérítéses immobilnak neveztük azokat, akik költségtérítéses hallgatóként kezdték a tanulmányaikat és úgy is folytatták. Felfelé mobilként soroltuk be azokat, akiknek sikerült a költségtérítéses képzésből államilag finanszírozott képzésbe átkerülni. Lefelé mobilak voltak azok a hallgatók, akik államilag finanszírozott képzésből költségtérítéses képzésbe kerültek. Az eredmények azt mutatták, hogy a stabil anyagi hátterű családok alacsony önköltségü képzésbe járó gyermekei tartoznak a költségtérítéses immobil típusba. A felfelé és lefelé mobilak felsőoktatási tanulmányi pályafutása során legalább egy alkalommal reális alternatívaként merült fel a felsőoktatásból való lemorzsolódás, főként azokon a képzési területeken, ahol a költségtérítés az európai átlagot meghaladóan magasabb összegü volt. Az önköltséges hallgatók dilemmáit megismerve, a kvalitatív kutatás nyomán megfogalmazódott az a kérdés, hogy milyen arányú és hogyan oszlik el területileg és társadalmilag a költségtérítésesek aránya Magyarországon, ezért a FELVI adatai alapján vizsgáltuk a 2018. évi általános felvételi eljárásban, nappali és levelező tagozaton költségtérítéses képzésre felvett alap- és osztatlan képzéses hallgatókat. ${ }^{1}$ Hangsúlyozzuk, hogy az alábbi adatok azokra a hallgatókra vonatkoznak, akik belépéskor vállalták a költségtérítés fizetését, azonban az önköltséges képzésre menet közben átsoroltak összetételéről egyelőre nincsenek statisztikai adataink.

\section{Területi egyenlötlenségek az önköltséges alapképzésben}

Az alapképzésbe felvett hallgatók közül minden negyedik hallgató fizet a képzésért (12700 fő). Arányuk azonban jelentős regionális eltéréseket mutat, több mint négyszeres is lehet a különbség egyes térségek között. A legmagasabb az arányuk a fővárosban és környékén. Ez gazdasági fejlettségét tekintve az ország forró pontja, s kiemelkedően sok olyan önköltséges képzés érhető itt el, melyekből a legnagyobb gazdasági haszon remélhető. Másrészt a fövárosban arányaiban több magasan kvalifikált vagy ritka szaktudással rendelkező foglalkoztatott él, az itt élő családok a kedvezőbb társadalmi státusuk átörökítése érdekében képesek támogatni a gyermekük továbbtanulását, és akár költségtérítést is fizetni (Hegedüs 2018a).

$\mathrm{A} z$ alapvetően jobb gazdasági mutatókkal rendelkező nyugat-magyarországi régiók területein vannak ugyan magasabb önköltséges képzésbe felvett hallgatói arányt mutató járások, de ezek mégsem tekinthetők homogén térségnek ebből a szempontból. A tanulók családiháttér-indexe, a szülők iskolázottsága az átlagnál magasabb (Híves 2015), a családok költségvetése valószínúleg lehetővé tenné a képzés finanszírozásához való hozzájárulást. A társadalmi státusbeli előnyök a jelentkezők jobb felkészültségében is visszaköszönnek, a tanulói teljesítmény kiemelkedő, a kompetenciaeredmények és az érettségi eredmények jobbak (Hegedüs 2016; Sebestyén-Hegedüs 2017; Sebestyén 2017). Emellett nincs is erős verseny az államilag támogatott férőhelyekért, ezért az itt élőknek nagyobb esélyük van a felsőoktatás államilag támogatott képzéseire való bejutásra.

\footnotetext{
Az ábrák MapInfo programmal készültek, és az elemzés során ahol lehetséges volt, ott közel egyenlő elemszámú kategóriákat alakítottunk ki a járásokból, ez azonban a hátrányos helyzetűeknél változik az alacsony elemszám miatt.
} 
A Dél-Alföld magasabb költségtérítéses arányszámai a gazdasági fejlettség mellett azzal magyarázhatók, hogy az ott tanuló gyermekek tanulmányi eredménye országos viszonylatban is jónak tekinthető, így fennáll annak a lehetősége, hogy a szülők a népszerü, magas presztízsű, magas bejutási pontszámmal jellemezhető és költségtérítéses formában induló szakokra járatják gyermeküket, vállalva ennek minden anyagi terhét. Békés megye, mint más területi elemzésekben, itt is eltér a régiójától. A térség a tanulói teljesítmény és gazdasági helyzet tekintetében elmarad a régió többi részétől, azonban az itt élők elkötelezettek az oktatás iránt, így gyengébb tanulói eredmények ellenére is megpróbálnak bejutni a felsőoktatásba, viszont pontjaik csak önköltséges képzésre elegendők.

Az országban több olyan térség van, melyet az elmúlt évtizedek kutatásai hátrányos helyzetűként azonosítottak (Pusztai 2006; Szemerszki 2010; Hives 2015). Ezek a térségek alacsony önköltséges aránnyal jellemezhetők, ami a térség lakóinak kedvezőtlenebb társadalmi-gazdasági helyzetével és alacsonyabb teljesítményével magyarázható (Hegedüs 2018a). Az ország északi, északkeleti térségeiben mind a családiháttér-index, mind az országos kompetenciamérés eredményei rendkívül alacsonyak. A magasabb társadalmi státuszú, jó eredményeket felmutató tanulók tehát kisebb arányban versenyeznek az államilag támogatott helyekért, ami nem teszi indokolttá a jobb tanulók költségtérítéses képzésbe való kiszorulását, így csökken a térségben az önköltséges hallgatók aránya. Korábban rámutattunk, hogy ebben a térségben a legmagasabb a hátrányos helyzetü hallgatók aránya. A térségben kiemelkedően magas arányú, alacsony társadalmi státusú, s emiatt gyengébb tanulmányi teljesítményủ jelentkezők szülei nem engedhetik meg maguknak az öröklött egyenlőtlenségek költségtérítés kifizetésével történő korrigálását, s induláskor nem vállalják a önköltséges képzések választását.

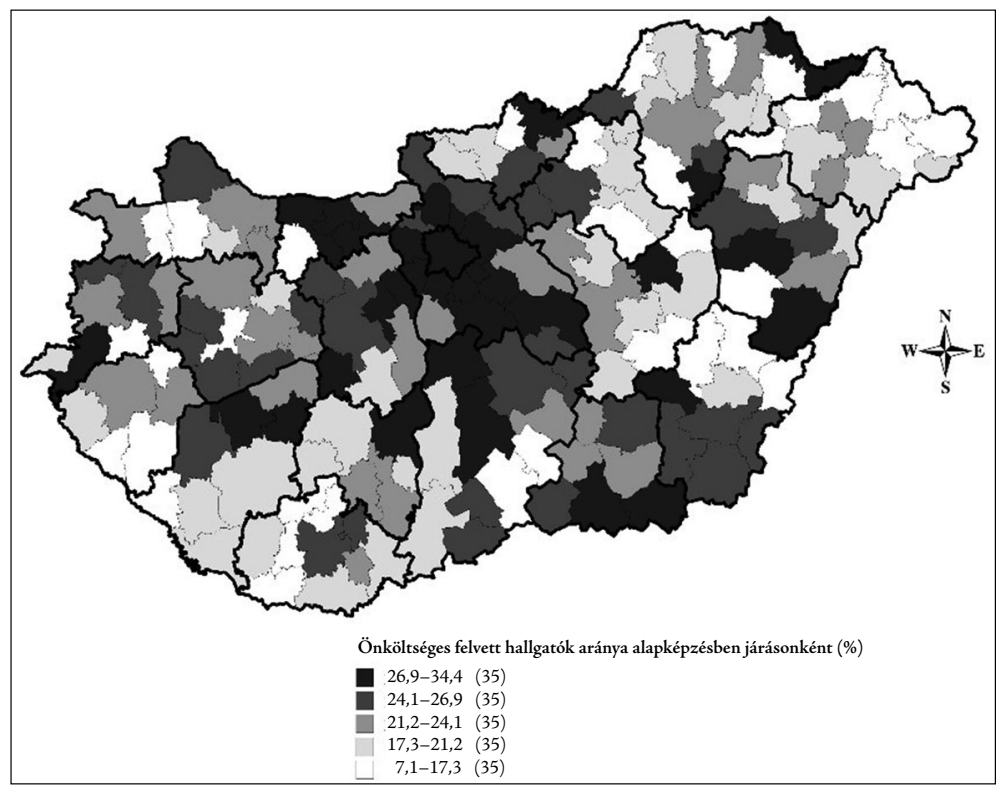

1. ábra: Alapképzésbe felvett önköltséges hallgatók aránya az általános felvételi eljárás során járásonként 2018-ban ( $N$ = 46677). Forrás: FELVI 2018 
Hallgatói vizsgálataink során a továbbtanulási motívumok között kiemelkedő helyen állt a felsőoktatási intézmény közelsége és a képzés állami finanszírozása mint a döntés elsődleges szempontja, ami a mobilizálható anyagiakkal való csekély mértékű rendelkezésre vall (Pusztai 2011; Tóth et al. 2019). A hátrányos helyzetért járó többletpontok, ha a felvételt nem is minden esetben segítik elő, de a hátrányos helyzetűek felvételi pontjai közelítik a szintén alacsony státusú, de nem hátrányos helyzetűként besorolt tanulókét, s ezzel nekik kicsit több esélyük van bekerülni a felsőoktatásba (Hegedüs 2018b). Amenynyiben azonban a kedvezőtlenebb társadalmi helyzetű családok gyermekei állami finanszírozású képzésbe kerülnek, de a teljesítményalapú finanszírozás rendszerében mégis átsorolják őket költségtérítéses képzésbe, a képzés megváltozott feltételeinek nem tudnak eleget tenni, s lemorzsolódnak.

\section{Önköltségesek az osztatlan képzésben}

2018-ban az osztatlan képzésbe 7280 hallgató került felvételre az általános felvételi eljárás során, az önköltségesek a felvettek 30,9\%-át teszik ki, így az alapképzéssel szemben közel minden harmadik felvett hallgató fizet a képzéséért. Az osztatlan képzés a szakokat tekintve nagyon összetett, mert magába foglalja a magas társadalmi elismertségü szakokat - mint például az orvos-, jogászképzéseket -, de beletartoznak a tanári végzettséget adó szakok is, melyre a társadalmi elismertség kevésbé jellemző. Az adataink alapján elmondható, hogy az osztatlan képzésbe felvett önköltséges hallgatók 94,4\%-a jogi képzési területre került be. A képzésért félévenként nagyjából 300000 Ft kérhető el, ami közel azonos a tanárképzés tandíjaival, ezzel szemben az orvosképzésért 1,3 millió Ft fölötti összeget kell fizetniük az önköltségeseknek, vagyis, az osztatlan szakok között

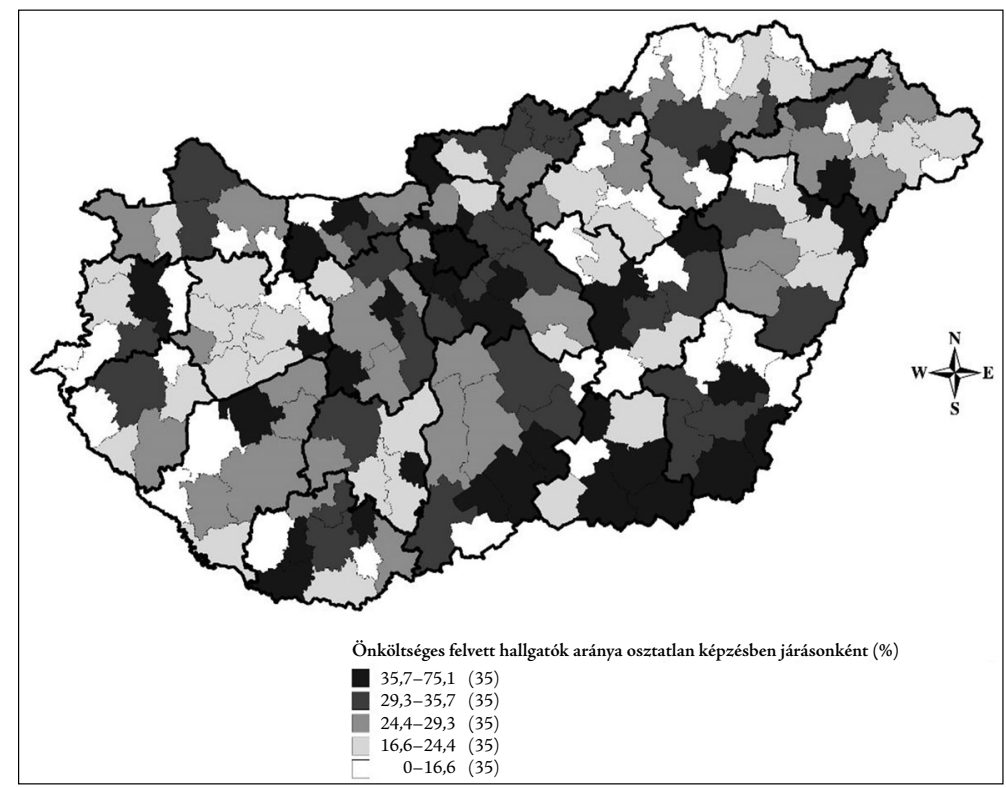

2. ábra: Osztatlan képzésbe felvett önköltséges hallgatók aránya általános felvételi eljárás során járásonként 2018-ban ( $N=6891)$. Forrás: FELVI 2018 
a jogászképzésnek van a legnagyobb megtérülése, ha költségtérítéses formában végzi el a hallgató (Fábri 2010; Róbert 2015).

A kutatás korlátját képezik esetenként az alacsony elemszámok, a 2. ábrán szemléltetett területi elemzés igen fragmentált képet mutat. Az adott térség társadalmi, gazdasági jellemzői, a szak térstruktúrája, a képzési kínálat sajátosságai, a képzési befektetés megtérülésével kapcsolatos meggyőződések mind szerepet játszhatnak a kialakult mintázatokban, de Északkelet- és Kelet-Magyarországon az alacsonyabb önköltséges hallgatói arányok ebben az esetben is a kedvezőtlen társadalmi-gazdasági jellemzőkkel magyarázhatók. A hátrányos helyzetű területek fiataljai számára relatíve túl költséges elhagyni a szülöi házat, s ha a költségtérítés mellett lakhatási, utazási, megélhetési költségek is felmerülnek, inkább lemondanak a vágyott szak választásáról (Hegedüs 2018a). A teljesítményalapú finanszírozás bevezetése ezen a területen még nagyobb kockázattal jár, hiszen a megkezdett tanulmányokba történt tanulói és állami befektetés nagy valószínűséggel kárba vész az extrém magas önköltségű formára való átsoroláskor.

\section{Hátrányos helyzetüek esélyei az önköltséges képzésekben}

Az Európai Unió célként jelölte meg, hogy a felsőoktatásba felvettek arányaiban a társadalmi arányoknak tükröződnie kell (Hrubos 2012). A hátrányos helyzetűek száma az elmúlt években drasztikusan csökkent, már az 1000 föt sem éri el, míg négy évvel ezelőtt, több mint háromezer hátrányos helyzetü került felvételre (Fehérvári et al. 2016). Attól lehet tartani, hogy ez elsősorban a 2013-ban bevezetett kritériumoknak köszönhető, s nem jelenti a tanulók társadalmi státusának emelkedését, vagyis kérdés, hogy a felsőoktatásba felvettek társadalmi struktúrája tükrözi-e a magyar társadalom struktúráját.

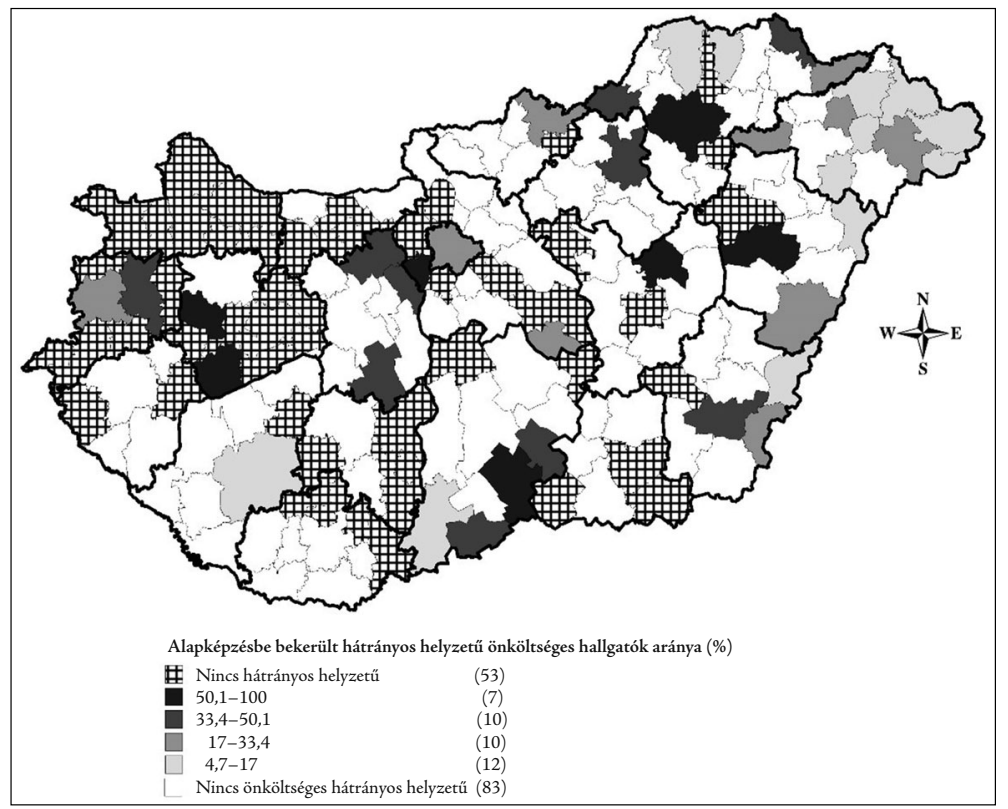

3. ábra: $A z$ alapképzésbe bekerült hátrányos helyzetű önköltséges hallgatók aránya járásonként $(N=467)$. Forrás: FELVI 2018 
A z általános felvételi eljárás során alapképzésbe 480 hátrányos helyzetű hallgató került be, melyből mindösszesen 63 hallgató volt önköltséges $(13,1 \%)$, ami arányaiban nézve a teljes alapképzésben mért százalékos érték fele. ${ }^{2} \mathrm{~A}$ hátrányos helyzetüek szakválasztását erősen befolyásolja, hogy olyan képzésekbe törekszenek, melyért nem kell fizetniük, s ahol kevesebb a kockázat a magas költségtérítéses formára való átsorolásra. A 3. ábra jól szemlélteti azt, hogy mely térségekből nem került be egy hátrányos helyzetű hallgató sem a vizsgált felvételi eljárásban a felsőoktatásba (négyzetrácsos minta), míg fehér színnel azt jelenítettük meg, hogy ha vettek is fel hátrányos helyzetü hallgatót, nem volt közöttük önköltséges.

Egyértelmüen látszik az északnyugati országrész és néhány fejlettebb járás gazdasági fejlettségbeli előnye. Az önköltséges képzésbe bekerültek magasabb arányai több esetben egybeesnek a fejlettebb járásokkal, valószínüleg a hátrányos helyzet megítélése a szigorú szabályozás ellenére relatív. A hátrányos helyzetủ északkeleti térségekben alacsony, de egyenletes eloszlás figyelhető meg, vagyis a felsőoktatási képzési központtól távol, hátrányos helyzetből indulva mégis nekirugaszkodnak a hallgatók az önköltséges képzésnek. Az önköltséges képzésben tanulókkal készített interjúk alapján elmondható, hogy ilyen esetben a hallgató általában komolyabb munkát vállal a tanulás mellett, s ez a belépéskor már fennálló lemorzsolódási rizikóját megsokszorozza, hiszen ennek egyenes következménye az időzavar, a gyengébb teljesítmény, a tanulmányok elhúzódása s a költségek megsokszorozódása. Több hátrányos helyzetűnek számító járásból nem is jelentkeztek költségtérítéses képzésre. Összefoglalva az a következtetés vonható le az adatokból, hogy ha az önköltséges képzés részaránya tovább nő, akkor a hátrányos

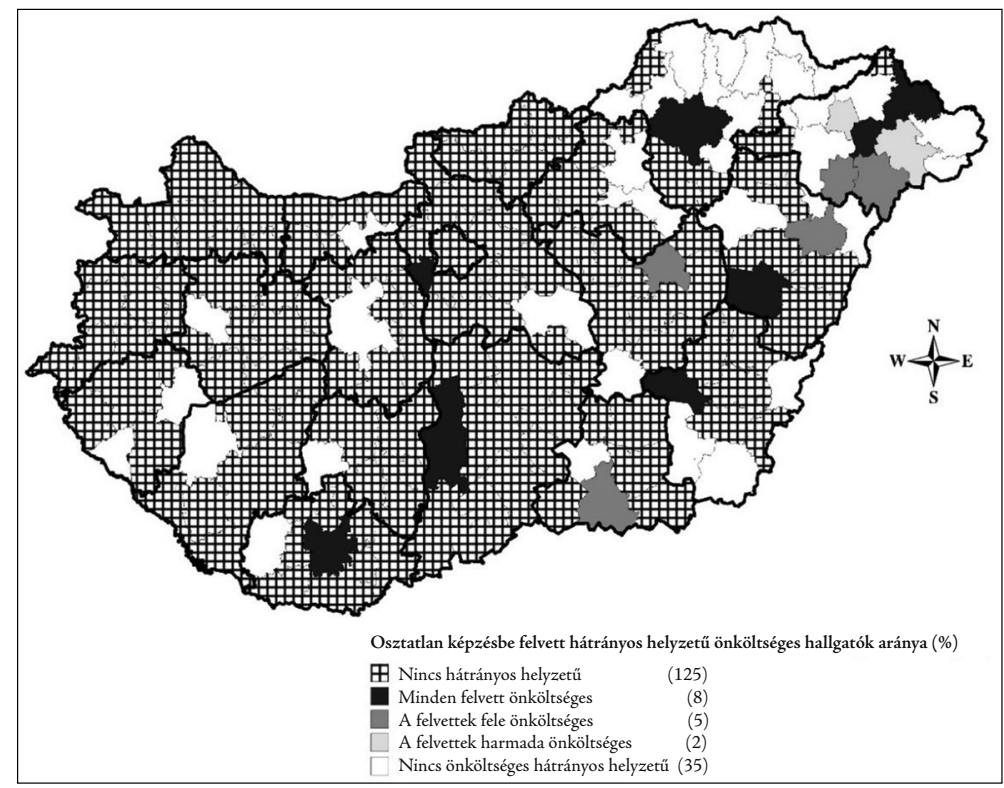

4. ábra: Az osztatlan képzésbe bekerült hátrányos helyzetü önköltséges hallgatók aránya járásonként $(N=71)$. Forrás: FELVI 2018

\footnotetext{
Megjegyezzük, hogy az alacsony elemszám miatt sok esetben csak egy-két hallgatóról beszélhetünk, ami a százalékos arányok magasabb értékét jelentheti.
} 
helyzetűek még jobban kiszorulnak a felsőoktatásból, és a társadalmi rétegek közötti különbség tovább erősödik.

Az osztatlan képzések erős szelektív karakterét húzza alá a hátrányos helyzetű hallgatók osztatlan képzésbe való bejutási aránya. Összesen 71 hátrányos helyzetű hallgató került felvételre osztatlan képzésbe, s ebből mindössze 15 fő vállalta azt, hogy a hosszabb futamidejű képzést önköltséges formában végzi el. Közülük 14 hallgató került be jogászképzésbe, egy fö gyógyszerészképzésbe, orvosképzésbe pedig senki. A 4. ábrán látható, hogy a Dunántúlon csupán egy hátrányos helyzetủ hallgató nyert felvételt költségtérítéses képzésbe. Egyértelmü, hogy a hátrányos helyzetű hallgatók többségében nem is próbálnak bekerülni a magasabb presztízsü, osztatlan képzési szakokra, legfeljebb a tanárképzés valamelyik szakára kerülnek be. Összességében tehát a felsőoktatás önköltséges formája valójában egy komoly szelekciós mechanizmust müködtet, amely a hátrányos helyzetű csoportok gyermekeinek közoktatásból hozott hátrányát tovább erősíti, sőt, az intézmények tanulást segítő, hátránykompenzáló tevékenysége nélkül bevezetett teljesítményalapú finanszírozás hosszabb távon teljesen kiszoríthatja őket egyes pályákról. A hátrányos helyzetủek befektetési stratégiáit ismerve egyértelműen megállapítható, hogy a diákhitel sem jelent megoldást számukra.

\section{Következtetések}

Tanulmányunkban a hallgatói lemorzsolódással foglalkozó kutatásunk eredményeit mutattuk be. Elsősorban arra koncentráltunk, hogy a felsőoktatásból lemorzsolódók ismeretlen világába bepillantást engedjünk. A már lemorzsolódott hallgatók körében végzett kvalitatív és kvantitatív vizsgálatunk legfontosabb tapasztalata, hogy a lemorzsolódott hallgatók nem homogén csoport, az anyagiak és munkavállalás miatt lemorzsolódók, a tanulmányi nehézségek és intézményi támogatás hiánya, valamint a felsőoktatási tanulmányokból való kiábrándulás sodorja őket a kudarcos hallgatói pályafutás felé, s olyanok is vannak köztük, akiket egyszerre több problémakör is érint. A 2019-ben felvett hallgatói adataink szerint a perzisztens és a lemorzsolódási rizikóval küzdő hallgatók között a legfontosabb különbség az anyagi stabilitás tekintetében mutatható ki. Végül az anyagi tekintetben legkiszolgáltatottabb hallgatók, a költségtérítésesek nyomába eredtünk, $\mathrm{s}$ azt vizsgáltuk, melyik csoportjuk számít a lemorzsolódás tekintetében a leginkább veszélyeztetettnek. Az önköltséges képzések már a jelentkezés és a tanulmányok elkezdése pillanatában hozzájárulnak az egyenlőtlenségek konzerválásához. A tanulmányok alatt költségtérítéses képzésbe átsorolt hallgatók összetételéről egyelőre nem rendelkezünk statisztikai adatokkal. Kutatásunk rámutat, hogy a probléma felelősségteljes kezelését nem lehet leegyszerűsített hallgatóképre, a felelőtlen és alkalmatlan hallgató sztereotípiájára építeni, mert ez hosszú távon súlyos emberi és anyagi erőforrásvesztéshez vezet.

\section{IRODALOM}

Arulampalam, W., Naylor, R. A. \& Smith, J. P. (2007) Dropping Out of Medical School in the Uk: Explaining the Changes Over Ten Years. Medical Education, Vol. 41. No. 4. pp. 385-94.

Bourdieu P. (1978) A társadalmi egyenlötlenségek újratermelödése. Budapest, Gondolat. Braxton, J. (2000, ed.) Reworking the student Departure Puzzle. Nashville, Vanderbilt. 
Brunsden, V., Davies, M., Shevlin, M., \& Bracken, M. (2000) Why do the Students Drop Out? A Test of Tinto's Model. Journal of Further and Higher Education, Vol. 24. No. 3. pp. 301-310.

Derény A A. (2015) Bizonyítékokra alapozott kormányzás és a kommunikáció képzés. Jelkép, Vol. 4. No. 1. pp. 1-21. doi:10.20520/Jel-Kep.2015.1.KLSZ.21.

Diem, A. \& Wolter, S. C. (2019) A Place Too Crowded to Study: The Impact of Student Cohort Growth on the Probability of University Dropout. Hungarian Educational Research Journal, Vol. 9. No. 2. pp. 189-212.

Dinyáné Szabó M., Pusztai G. \& Szemerszki M. (2019) Lemorzsolódási kockázat az orvostanhallgatók körében. Orvosi Hetilap, Vol. 160. No. 21. pp. 829-834.

Dwenger, N., Storck, J. \& Wrohlich, J. (2012) Do Tuition Fees Affect the Mobility of University Applicants? Evidence from a Natural Experiment. Economics of Education Review, Vol. 31. No. 1. pp. 155-167. DOI: 10.1016/j.econedurev.2011.10.004

Eurydice (2018) National Student Fee and Support Systems in European Higher Education. No. 19. Brussels, European Commission EACEA Eurydice.

FÁвR I. (2010) A hazai felsőoktatási jelentkezések fontosabb összefüggései. Felsőoktatási Mühely, Vol. 4. No. 1. pp. 9-28.

Fehérvári A. (2015) Lemorzsolódás és a korai iskolaelhagyás trendjei. Neveléstudomány: oktatás - kutatás - innováció, Vol. 3. No. 3. pp. 31-47.

Fehérvári A., Misley H., Szemerszki M., Veroszta Zs., Csordás K., Gáll B. B., Győrpál Zs. \& Tossenberger T. (2016) A felsőoktatás szociális dimenziója. Hátrányos belyzetü csoportok hozzáférése és részvétele a felsőoktatásban cimü kutatás. Budapest, Tempus Közalapítvány.

FÉnyes H. \& Pusztai G. (2006) Férfiak hátránya a felsőoktatásban egy regionális minta tükrében. Szociológiai Szemle, Vol. 15. No. 1. pp. 40-59.

Fenyves V., Bácsné Bába É., Szabóné Szőke R., Kocsis I., Juhász Cs., Máté E. \& Pusztai G. (2017) Kísérlet a lemorzsolódás mértékének és okainak megragadására a Debreceni Egyetem Gazdaságtudományi Kar példáján. Neveléstudomány: oktatás - kutatás - innováció, Vol. 5. No. 3. pp. 5-14.

Garami E. (2013) Kistérségi jellemzők együttes hatása az oktatás eredményességére és a továbbtanulási döntésekre. Doktori disszertáció. Debrecen, Debreceni Egyetem.

Hatos, A. \& Pop, A. (2013) Commitment to the Goal of Completing Studies in Higher Education. Dropout Risk of the Students From Social Science Specialisation from the Three Romanian Public Universities that Participate in Project Practipass. Annals of University of Oradea, Fascicle Sociology-Philosophy E Social Work, Vol. 12. No. 12. pp. 5-16.

Hegedưs R. (2016) Tizedik osztályos tanulók teljesítményének területi különbségei. Iskolakultúra, Vol. 26. No. 12. pp. 16-30.

Hegedưs R. (2018a) Hátrányos helyzetűek a közép- és felsőfokú oktatásban. Hátrányos helyzetű tanulók középiskolai teljesítménye és felsőoktatásba való bejutásuk jellemzői, különös tekintettel a területi különbségekre. Doktori disszertáció. Debrecen, Debreceni Egyetem.

Hegedưs R. (2018b) Mennyit ér plusz 40 pont egy vidéki karon? In: Tótr D. A. (ed.) $A z$ oktatás gazdagsága. Debrecen, CHERD-Hungary. pp. 167-179.

Híves T. (2015) Területi oktatáskutatás. Vizsgálatok az iskolázás területi folyamatairól. Doktori disszertáció. Pécs, Pécsi Tudományegyetem.

Нruвos I. (2012) A társadalmi egyenlőtlenségek új színterei a felsőoktatásban. Iskolakultúra, Vol. 22. No. 1-2. pp. 85-90. 
Hübner, M. (2009) Do Tuition Fees Affect Enrollment Behavior? Evidence from a 'Natural Experiment' in Germany. Economics of Education Review, Vol. 31. No. 6. pp. 19-46. DOI: $10.2139 /$ ssrn.1495119.

Kенм, B. (2014) Editorial. European Journal of Education, Vol. 49. No. 4. pp. 453-456.

Kehm, B., Larsen, M. L. \& Sommersel, H. B. (2019) Student Dropout from Universities in Europe. Hungarian Educational Research Journal, Vol. 9. No. 2. pp. 147-164.

Kozma T. \& Pusztai G. (2009) Kié a doktori iskola? Educatio, Vol. 18. No. 1. pp. 64-74.

Kun A. I. (2015) A báránybőr hatás és a bolognai folyamat Magyarországon. In: Tótн Z. (ed.) Új kutatások a neveléstudományokban 2014. Magyar Tudományos Akadémia Pedagógiai Bizottsága. pp. 220-229.

Markos, V., Kocsis, Zs. \& Dusa, Á. R. (2019) Different Forms of Civil Activity and Employment in Hungary and Abroad, and the Development of Student Drop-out. Central European Research Journal, Vol. 1. No. 1. pp. 68-79.

Merill, B. (2015) Determined to Stay or Determined to Leave? Journal Studies in Higher Education, Vol. 40. No. 10. pp. 1859-1871.

O’Neill, L. D., Wallstedt, B., Eika, B. \& Hartvigsen, J. (2011) Factors Associated with Dropout in Medical Education: A Literature Review. Medical Education, Vol. 45. No. 5. pp. 440-454. DOI: 10.1111/j.1365-2923.2010.03898.x.

Pascarella, E. T. \& Terenzini, P. T. (2005) How College Affects Students. A Third Decade of Research. San Francisco, Jossey-Bass.

Pervin, A., Reik, L. E. \& Dalrymple, W. (eds) (1996) The College Dropout and the Utilization of Talent. Princeton, Princeton University Press.

Pusztai G. (2006) Egy határmenti régió hallgató-társadalmának térszerkezete. In: JuHÁsz E. (ed.) Régió és oktatás. Debrecen, Doktoranduszok Kiss Árpád Közhasznú Egyesülete. pp. 43-57.

Pusztai G. (2011) A láthatatlan kéztól a baráti kezekig. Budapest, Új Mandátum Kiadó.

Pusztai, G., Fényes, H., Szigeti, F. \& Pallay, K. (2019) Dropped-out Students and the Decision to Drop-out in Hungary. Central European Research Journal, Vol. 1. No. 1. pp. 45-67.

Pusztai, G. \& Kocsis, Zs. (2019) Combining and Balancing Work and Study on the Eastern Border of Europe. Social Sciences, Vol. 8. No. 6. pp. 193.

Pusztai, G. \& Szabó, P. Cs. (2008) The Bologna Process as a Trojan Horse. European Education, Vol. 40. No. 2.pp. 85-103.

Pusztai G. \& Szigeti F. (2018) Lemorzsolódás és perzisztencia a felsöoktatásban. Debrecen, Debreceni Egyetemi Kiadó.

Reay, D., Crozier, G. \& Clayton, J. (2009) Strangers in Paradise? Working-class Students in Elite Universities. Sociology, Vol. 43. No. 6. pp. 1103-1121.

RóвеRт P. (2015) Osztály- és rétegződéskutatási dilemmák a magyar társadalomban. Replika, Vol. 92-93. No. 3-4. pp. 77-93.

Ross S., Cleland, J. \& Joan Macleod, M. (2006) Stress, Debt and Undergraduate Medical Student Performance. Medical Education, Vol. 40. No. 6. pp. 584-589. DOI: 10.1111/j.1365-2929.2006.02448.x.

Schnepf, S. (2014) Do Tertiary Dropout Students Really Not Succeed in European Labour Markets? Discussion Paper, IZA DP No. 8015.

Sebestyén K. (2017) Gimnáziumi és szakközépiskolai kétszintű érettségi eredmények vizsgálata német nyelvből. Educatio, Vol. 26. No. 1. pp. 121-128. 
Sebestyén K. \& Hegedưs R. (2017) Középiskolások idegen nyelvi, szövegértési és matematikai eredményeinek vizsgálata társadalmi és területi tényezők mentén. Modern Nyelvoktatás, Vol. 23. No. 2-3. pp. 21-33.

Seidman, A. (2005, ed.) College Student Retention: Formula for Student Succes. Westpont, Praeger Publishers.

Stiburek, S., Vlk, A. \& Svec, V. (2017) Study of the Success and Dropout in the Higher Education Policy in Europe and V4 Countries. Hungarian Educational Research Journal, Vol. 7. No. 1. pp. 43-56.

Szemerszki M. (2010) Regionális eltérések a harmadfokú továbbtanulásban. In: Kozma T. \& Ceglédi T. (eds) Régió és oktatás: A Partium esete. Debrecen, CHERD. pp. 172-188.

Szemerszki M. (2015) A felsőfokú tanulmányi előmenetelt és sikerességet befolyásoló tényezők. In: Pusztai G. \& Kovács K.: Ki eredményes a felsőoktatásban? Budapest-Nagyvárad, UMK-PPPS. pp. 108-118.

Thomas, L. (2019) Developing a National Approach to Improve Student Success in Higher Education: New Insights from a Comparative Analysis of England and the Czech Republic. Hungarian Educational Research Journal, Vol. 9. No. 2. pp. 165-188.

Tierney, W. G. (2000) Power, Identity and Dilemma of College Student Departure. In: J. M. Braxton (ed.) Reworking the Student Departure Puzzle. Nashville, Vanderbilt University Press. pp. 213-235.

Tinto, V. (1975) Dropout from Higher Education. A Theoretical Synthesis of Recent Research, Vol. 45. No. 1. pp. 89-125.

Tinto V. (1993) Leaving College: Rethinking the Causes and Cures of Student Attrition. Chicago, University of Chicago Press.

Toth, D. A., Szemerszki, M., Cegledi, T. \& Máthé-Szabó, B. (2019) The Different Patterns of the Dropout According to the Level and the Field of Education. Hungarian Educational Research Journal, Vol. 9. No. 2. pp. 257-269.

Váradi, J., Demeter-Karászi, Zs. \& Kovács, K. (2019) The Connection between Extracurricular, Leisure Time Activities, Religiosity and the Reason for Drop-out. Central European Research Journal, Vol. 1. No. 1. pp. 80-92.

Vossensteyn, H. (2015) Dropout and Completion in Higher Education in Europe. Luxembourg, Publications Office of the European Union.

Wolter, S. C., Diem, A. \& Messer, D. (2014) Drop-outs from Swiss Universities: An Empirical Analysis of Data on All Students between 1975 and 2008. European Journal of Education, Vol. 49. No. 4. pp. 471-483.

A cikk a Creative Commons Attribution 4.0 International License (https://creativecommons.org/licenses/ by/4.0/) feltételei szerint publikált Open Access közlemény, melynek szellemében a cikk bármilyen médiumban szabadon felhasználható, megosztható és újraközölhető, feltéve, hogy az eredeti szerző és a közlés helye, illetve a CC License linkje és az esetlegesen végrehajtott módosítások feltüntetésre kerülnek. (SID_1) 